\title{
Moringa Leaf Extracts as Biostimulants-inducing Salinity Tolerance in the Sweet Basil Plant
}

\author{
Raifa Ahmed Hassanein, Amal Fadl Abdelkader\#, Heba Mohammed Faramawy \\ Department of Botany, Faculty of Science, Ain Shams University, Cairo, Egypt.
}

$\mathbf{H}$ ORTICULTURE plants are constantly exposed to salinity problems during growing. Biostimulants from plants origin known to protect plants growth and improve their productivity within a varied conditions of salt stress. To investigate Moringa plants (Moringa oleifera, MO and Moringa peregrena, MP) activity as biostimulants, sweet basil (Ocimum basilicum L. cv. cispum) plants grown with/or without salt stress were irrigated using aqueous leaf extracts from both species. Two hundred grams of fresh Moringa leaves were homogenized in one liter distilled water, filtered and the dilutions: $2.5 \%, 5.0 \%, 10 \%$ and $20 \%$ were made. In stressed basil, proline and malondialdehyde had increased then decreased significantly with both Moringa extracts, particularly with MP treatment. Compared to control basil, $10 \%$ was the best concentration that caused enlargements of basil leaf area by $60 \%$ during salt stress. On applying 10\% MO and MP extracts to salt-stressed basil, growth parameters like shoot length were increased by $32 \%$ and $38 \%$, shoot fresh weight by $50 \%$ and $109 \%$, shoot dry weight by $123 \%$ and $84 \%$, number of branches by $75 \%$ and $87 \%$, root length by $40 \%$ and $63 \%$ and root dry weight by $142 \%$ and $225 \%$, respectively. MO treatment led to a significant increase in anthocyanin, total carbohydrates and superoxide dismutase in basil. Alternatively, MP increased ascorbic acid oxidase actively in basil leaf. The varied chemical composition of Moringa species underlined the resistance strategies in basil. We hypothesized that the efficacy might even become much more potent on basil with the simultaneous irrigation using the two species of Moringa.

Keywords: Antioxidant enzymes, Growth parameters, Malondialdehyde, Ocimum basilicum L. cv. cispum, Proline, Salt stress.

\section{Introduction}

The presence of increased salt ions in irrigation water or soil often leads to soil salinization and crop plant dehydration (Zhu, 2001). Salinity is an ancient, serious abiotic problem that confers deleterious impacts on agriculture in many parts of the world (Abdel Latef, 2010). In fact, millions of hectares have annually been affected due to salinity (Sheng et al., 2008). Salinity is associated with disturbance of plant water relation ending with physiological drought and malfunctions of homeostasis (Munns, 2002 and Rady, 2011). Furthermore, it interferes with water uptake by roots, prevents solubility of necessary soil components and threatens the nutritional balance via enhancing the uptake of harmful ions from the soil instead of nutrients (Silva et al., 2008). Moreover, salinity was the main factor inducing photorespiration and reactive oxygen species
(ROS). However, plant tolerance is the strategy capable for development at various levels in plants (Munns \& Tester, 2008). Thereby, to ameliorate the damage caused by ROS, plants evolve defense strategy in form of production of various antioxidant enzymes like superoxide dismutase (SOD), catalase (CAT), ascorbic acid oxides (ASO), peroxidase (POX), ascorbate peroxidase (APX) and polyphenol oxidase (PPO). These enzymes can prevent ROS production and action (Alscher et al., 2002).

Sweet basil belongs to lamiaceaeas aromatic ornamental plant native to tropical and subtropical regions. It can be used as a medicine for several health problems (Simon et al., 1990) and have been frequently utilized in various industries (Makri \& Kintzois, 2007). Thus, basil is demanded by various resources. The famous natural oils that are found in basil are linalool, methyl cinnamate,

"Corresponding author email: amal.abdelkader@yahoo.com

DOI: 10.21608/ejbo.2019.5989.1242

Edited by: Prof. Dr. Wedad Kasim, Faculty of Science, Tanta University, Tanta, Egypt.

C2019 National Information and Documentation Center (NIDOC) 
methyl chavicol, eugenol and geraniol (Sajjadi, 2006). Previous studies reported that basil growth, metabolism and yield are affected by osmotic and ionic stress due to salinity (Ashraf \& Harris, 2004 and Saqib et al., 2012).

In agriculture, exposed plants to mild stress using $100 \mathrm{mM} \mathrm{NaCl}$ provides insights about the primary tolerance and acclimation strategies in plants. In the literature, treatment of lens plant using $100 \mathrm{mM} \mathrm{NaCl}$ reduced germination, suppressed growth, diminished pigment content and dry matter, induced cell membrane instability and increased Malondialdehyde (MDA) for the overexpression of reactive oxygen species and antioxidant enzymes induction (Aydemir \& Erez, 2010). MDA is the global indicator of lipid peroxidation (Wada et al., 2008) and the biomarker of membrane injury (Sharma et al., 2005). Recently, exogenous application of nitric oxide in basil alleviated salinity symptoms and raised the level of biochemical activities required for growth (Saeidnejad et al., 2013). However, basil plants develop stress adaptation strategy in form of proline induction. Proline is the interfering osmoticum with stabilizing protein and membrane (Kardpol \& Rao, 1985) and involved with scavenging the free radicals (Blokhina et al., 2003).

Biostimulants were recently defined as the materials capable to promote, with their minute quantities, plant growth and facilitate nutrient uptake during abiotic stress (Colla \& Rouphael, 2015 and Du Jardin, 2015). Protein hydrolysates including, betaines, amino-acids, polyamines, non-protein amino acids, hormones and other nitrogenous compounds shown to play multiple roles as biostimulants of plant growth, metabolic production and recovery during environmental stress (Vranova et al., 2011 and Colla et al., 2015). Recently discovered that the antioxidant enzymes, sterols, polyamines and phytohormones like auxins, gibberellins and cytokinins extracted from seaweeds were considered potent biostimulants in stressed plants. They activated the hormone biosynthetic genes (Craigie, 2011) and regulated endogenous stress responsive genes (Battacharyya et al., 2015).

In addition to thirteen other genera, Moringa belongs to family Moringaceae (Olson, 2002). Two widely grown Moringa species in Egypt were used in this study as biostimulants of basil agriculture.
The first species: Moringa oleifera Lam. (MO) is a deciduous tree (7-12m height) with thick grey bark, white flowers and long green pods. MO is natively growing in Pakistan, Bangladesh, Afghanistan and India (Meneghel et al., 2013) and used in medicine to produce vitamins, antioxidants, ascorbate, zeatin, minerals, and purine adenine derivatives of cytokinin and amino acids (Siddhuraju \& Becker, 2003; Basra et al., 2009; Mahmood et al., 2010; Becker, 2013 and Hussain et al., 2013). Moringa leaves have also several biological activities as immune-boosting agent and tumor-suppressive effects (Fiazi et al., 1995). The second species: Moringa peregrina, Forresk (MP) is cultivated in Egypt (Abd El-Wahab et al., 2004). MP is growing fast, $15 \mathrm{~m}$ height tree and recognized by grey or green bark, long leaves and yellowish white to pink flowers. Leaves and pods of MP tree enclose nutritional components like vitamin A, B and $\mathrm{C}$, minerals, calcium, protein, low fats and carbohydrates, which all considered crucial for human health and liver stock (Alkahtani \& AbouArab, 1993 and Price, 2000).

So far, little is known about the role of Moringa plants as biostimulants. The present study devoted to underline the possible effect of leaf extracts from the two species of Moringa trees on stimulating stress tolerance in basil. The aim of this research is studying the effect of different concentrations of aqueous leaf extracts from the two Moringa species on tolerance strategies that evolved from the improved growth along with the amended metabolic profile.

\section{Materials and Methods}

\section{Plant material, leaf extraction and experimental design}

Fully expanded leaves and tender branches were collected from two cultivated Moringa trees (M. oleifera Lam and M. peregrina, Foressk) in El-Orman garden, El-kanater El-khairia region, Kalubiah Governorate, Egypt, during day time $\left(28^{\circ} \mathrm{C}\right.$, June/ 2015). Two hundred grams were extracted in $500 \mathrm{ml} \mathrm{H}_{2} \mathrm{O}$ using locally fabricated machine (Foidle et al., 2001). The extract was filtered through muslin cloths and centrifuged at $800 \mathrm{xg}$ for $15 \mathrm{~min}$. The supernatant was completed to one liter then dilutions were made $(20 \%, 10 \%, 5 \%, 2.5 \%)$ and kept at $4{ }^{\circ} \mathrm{C}$ till used. The experimental design was factorial based on completely randomized design. The sweet basil seeds were purchased from Agricultural Research 
Centre, Dokki, Cairo, Egypt, subjected to $5 \mathrm{~min}$ surface sterilization using $1 \%$ sodium hypochlorite $(\mathrm{NaClO})$ solution and washed thoroughly using distilled water. The greenhouse experiment was controlled for temperature $\left(25^{\circ} \mathrm{C} / 20^{\circ} \mathrm{C}\right.$, day/night), humidity (33\%) and radiation $(330 \mu \mathrm{mol} \mathrm{m}-2 \mathrm{~s}-1)$. Cultivation of basil seeds took place in plastic pot $(15 \mathrm{~cm}$ diameter, $15 \mathrm{~cm}$ deep) and the planting process started on 15/06/2015 for six weeks until the harvesting and sampling date on 30/07/2015. Prior planting each pot was equally filled with clay: sandy soils (2:1) and irrigated with tap water to $70 \%$ water holding capacity. After one week, thinning was carried out to leave 5 plants in each pot. Two weeks following sowing, the pots were divided into 18 groups with five replicates in each group: 1- Plants left without treatment (control), 2- Treated plants with $20 \%$ Moringa oleifera leaf extract (OLE), 3- Treated Plants with OLE (10\%), 4- Treated plants with 5\% OLE, 5- Treated plants with 2.5\% OLE, 6- Treated plants with $20 \%$ Moringa peregrena (PLE) leaf extract, 7- Treated plants with 10\% PLE, 8- Treated plants with 5\% PLE, 9- Treated plants with 2.5\% PLE, 10 - Treated plants with $100 \mathrm{mM} \mathrm{NaCl}, 11$ - Treated plants with $100 \mathrm{mM} \mathrm{NaCl}+20 \%$ OLE, 12 - Treated plants with $100 \mathrm{mM} \mathrm{NaCl}+10 \%$ OLE, 13 - Treated plants with $100 \mathrm{mM} \mathrm{NaCl}+5 \%$ OLE, 14 - Treated plants with $100 \mathrm{mM} \mathrm{NaCl}+2.5 \%$ OLE, 15 - Treated plants with $100 \mathrm{mM} \mathrm{NaCl}+20 \%$ PLE, 16 - treated plants with $100 \mathrm{mM} \mathrm{NaCl}+10 \%$ PLE, 17 - Treated plants with $100 \mathrm{mM} \mathrm{NaCl}+5 \%$ PLE and 18- Treated plants with $100 \mathrm{mM} \mathrm{NaCl}+2.5 \%$ PLE.

The plants were irrigated with $40 \mathrm{ml}$ OLE or PLE alone or in combination with $40 \mathrm{ml} \mathrm{NaCl}$ $(100 \mathrm{mM})$ at weeks 2.3 and 4 from sowing and the plants were harvested after 6 weeks from sowing.

Biochemical analysis of sweet basil leaf and root

The biochemical composition including the photosynthetic pigments, proline, carbohydrates, malondialdehyde and the antioxidant enzymes were analysed and determined in exposed and unexposed basil to salt stress treated with only $10 \%$ Moringa leaf extract.

\section{Estimation of proline}

Free proline was determined according to Bates et al. (1973). Acid ninhydrin reagent was prepared by warming $1.25 \mathrm{~g}$ ninhydrin in $30 \mathrm{ml}$ glacial acetic acid and $20 \mathrm{ml} 6 \mathrm{M}$ phosphoric acid with agitation until dissolved; kept cool and stored at $4{ }^{\circ} \mathrm{C}$. The reagent remains stable for $24 \mathrm{hr}$.
Approximately $0.1 \mathrm{~g}$ of macerated dried tissue was homogenized in $10 \mathrm{ml}$ of $3 \%$ aqueous sulfosalicylic acid, then filtered through filter paper Whatman No. 2. Two $\mathrm{ml}$ of the filtrate were mixed with $2 \mathrm{ml}$ glacial acetic acid and $2 \mathrm{ml}$ of the acid ninhydrin reagent in a test tube and heated for $1 \mathrm{hr}$ at $100^{\circ} \mathrm{C}$. The reaction mixture was extracted with $4 \mathrm{ml}$ toluene, mixed vigorously in a test tube for 15-20sec. The chromophore containing toluene was aspired from the aqueous phase and warmed to room temperature. The absorbance was read at $520 \mathrm{~nm}$ using toluene as blank. The proline concentration was determined using stander curve and calculated on a dry matter basis. Free proline was measured per milligram in $100 \mathrm{~g}$ dry weight.

\section{Estimation of photosynthetic pigments}

The photosynthetic pigments (chlorophyll a, chlorophyll $\mathrm{b}$ and carotenoids) were determined in the leaves of the investigated plant. The spectrophotometric method recommended by Metzner et al. (1965) was used. A known fresh weight of leaves was homogenized in $85 \%$ aqueous acetone for $5 \mathrm{~min}$. The homogenate was centrifuged and the supernatant was made up to volume with $85 \%$ aqueous acetone. The extinction was measured against a blank of pure $85 \%$ aqueous acetone at 3 wave lengths of 452.5, 644, $663 \mathrm{~nm}$ using Spectrocolourimeter DC Tiny 25III Model TUDC12B4. Taking into consideration the dilutions made of the pigment fraction, chlorophyll $\mathrm{a}$, chlorophyll $\mathrm{b}$ and carotenoids were determined in gram fresh weight using the following equations:

Chlorophyll a= 10.3 E663 -0.918 E644= $\quad \mu \mathrm{g} /$ $\mathrm{ml}$

Chlorophyll $b=19.7$ E644 -3.87 E663 $=\quad \mu \mathrm{g} / \mathrm{ml}$ Carotenoids $=4.2$ E425.5- (0.026 chlorophyll a + 0.426 chlorophyll $\mathrm{b})=\quad \mu \mathrm{g} / \mathrm{ml}$

Finally, the pigment contents were calculated as $\mu \mathrm{g} \mathrm{g}^{-1}$ dry weight of leaves.

\section{Estimation of carbohydrates}

The plant material was rapidly dried in an oven at $80^{\circ} \mathrm{C}$ to a constant weight and then ground to a fine powder.

Extraction and estimation of soluble sugars: A known weight of dried tissues was homogenized with $80 \%$ ethanol then put in a boiling water bath with shaking for $15 \mathrm{~min}$. After cooling, the extract was filtrated and the filtrate was oven dried at $60^{\circ} \mathrm{C}$ then dissolved in a known volume of water to be 
ready for determination of soluble sugars. The anthrone sulphuric acid method carried out by Whistler et al. (1962) was used for determination of soluble sugars. The anthrone reagent consists of 0.2 anthrone (Merck) and $100 \mathrm{ml} 95 \% \mathrm{H}_{2} \mathrm{SO}_{4}$. These were successively mixed in a conical flask under continuous cooling. This reagent should be always freshly prepared. $0.1 \mathrm{ml}$ of soluble sugar solution was put in a clear pyrex test tube and mixed with $10 \mathrm{ml}$ of anthrone reagent. The samples were then heated at $100^{\circ} \mathrm{C}$ in a water bath for exactly $7 \mathrm{~min}$, after which it was directly cooled under tap water. The developed blue green colour was read at a wavelength of $620 \mathrm{~nm}$ against a blank contain only water and anthrone reagent using Spectocolourimeter DC Tiny 25III Model TUDC12B4. A calibration curve using pure glucose was carried out.

Extraction and estimation of polysaccharides: The dry residue left after extraction of soluble carbohydrate was used for the determination of polysaccharides. A known weight of dried material was added to $10 \mathrm{ml} 1.5 \mathrm{~N}$ sulfuric acid in sugar tubes with air reflux and heated at $100^{\circ} \mathrm{C}$ in a water bath for $6 \mathrm{hr}$. The hydrolysate was made up to a known volume to be ready for polysaccharide determination by method of anthrone sulphuric reagent (Whistler et al., 1962). A calibration curve using pure glucose was made, from which the data were calculated as $\mathrm{mg} / \mathrm{g}$ dry weight.

Total carbohydrates: Total carbohydrate contents were calculated per gram in $100 \mathrm{~g}$ dry weight as sum of soluble sugars and polysaccharides amounts of the sample.

Extraction and estimation of lipid peroxidation product (MDA)

Lipid peroxidation was measured following the method described by Heath \& Pecker (1968), referring to malondialdehyde (MDA) produced by thiobabituric acid reactions.

Extraction and assaying activity of certain antioxidant enzymes

The extraction performed according to Mukheriee \& Choudhuri (1983). The activity of superoxide dismutase (SOD, EC 1.15.1.1) was determined by the method recorded by Marklund \& Murklund (1974). Assays of catalase (CAT, EC 1.11.1.6), polyphenol oxidase (PPO) and peroxidase (POX) activities measured by a method described by Kar \& Mishra (1976). Assay of ascorbate peroxidase (APX, EC 1.11.1.11) activity assay undertaken using a method described by Koricheva et al. (1997). Assay of ascorbate oxidase (ASO) activity determined by the method described by Diallins et al. (1997).

\section{Statistical analysis}

Data were means of five variables from three independent experiments. \pm SD determined using Microsoft excel, ver. 2008. Data were analysed using simple variance analysis (ANOVA), SPSS ver. 17 , and the means compared with LSD at $\mathrm{P}=$ 0.05 and Duncan's test.

\section{Results}

Effects of irrigation using MO and MP leaf extracts in basil culture

Evidence of general growth improvement has been detected upon basil plants irrigation with gradual dilutions of leaf extracts from MO and MP under normal conditions. Moreover, the growth parameters in salinized basil have significantly improved when extracts from both Moringa leaves were treated at any concentration in combination with $\mathrm{NaCl}$ (Fig. 1). However, 10\% concentration had influenced growth much better, whereas $2.5 \%$ resulted in the lowest response.

\section{Salt-stress experiment}

Six weeks old basil length was 24.77, 28.7, $29.0,30.78$ and $28.63 \mathrm{~cm}$ in treated basil with $0 \%$, $2.5 \%, 5 \%, 10 \%$ and $20 \%$ leaf extract concentration from MP, respectively. On the other hand, shoot length was 26.62, 28.09, 29.77 and $27.22 \mathrm{~cm}$ for $2.5 \%, 5 \%, 10 \%$ and $20 \%$ MO leaf extracts, respectively.

Irrigation of basil plants using 10\% MO and MP leaf extracts in salt experiment resulted in basil length increase by $32 \%$ and $38 \%$ and in $50 \%$ and $109 \%$ increase of shoot fresh weight, respectively (Fig. 1 A \& B).

Basil plant exhibited $60 \%$ enlargement of leaf area when irrigated with $10 \%$ MO or MP leaf extracts (Fig. 1 C). Furthermore, shoot dry mass increased by $123 \%$ and $84 \%$ with $\mathrm{MO}$ and MP extracts, respectively (Fig. 1 D). Number of branches increased by $75 \%$ and $87 \%$ (Fig. 1 E), root length increased by $40 \%$ and $63 \%$ and root dry weight increased by $142 \%$ and $228 \%$, when MO and MP were applied during irrigation, respectively (Fig. 1 F \& G). 

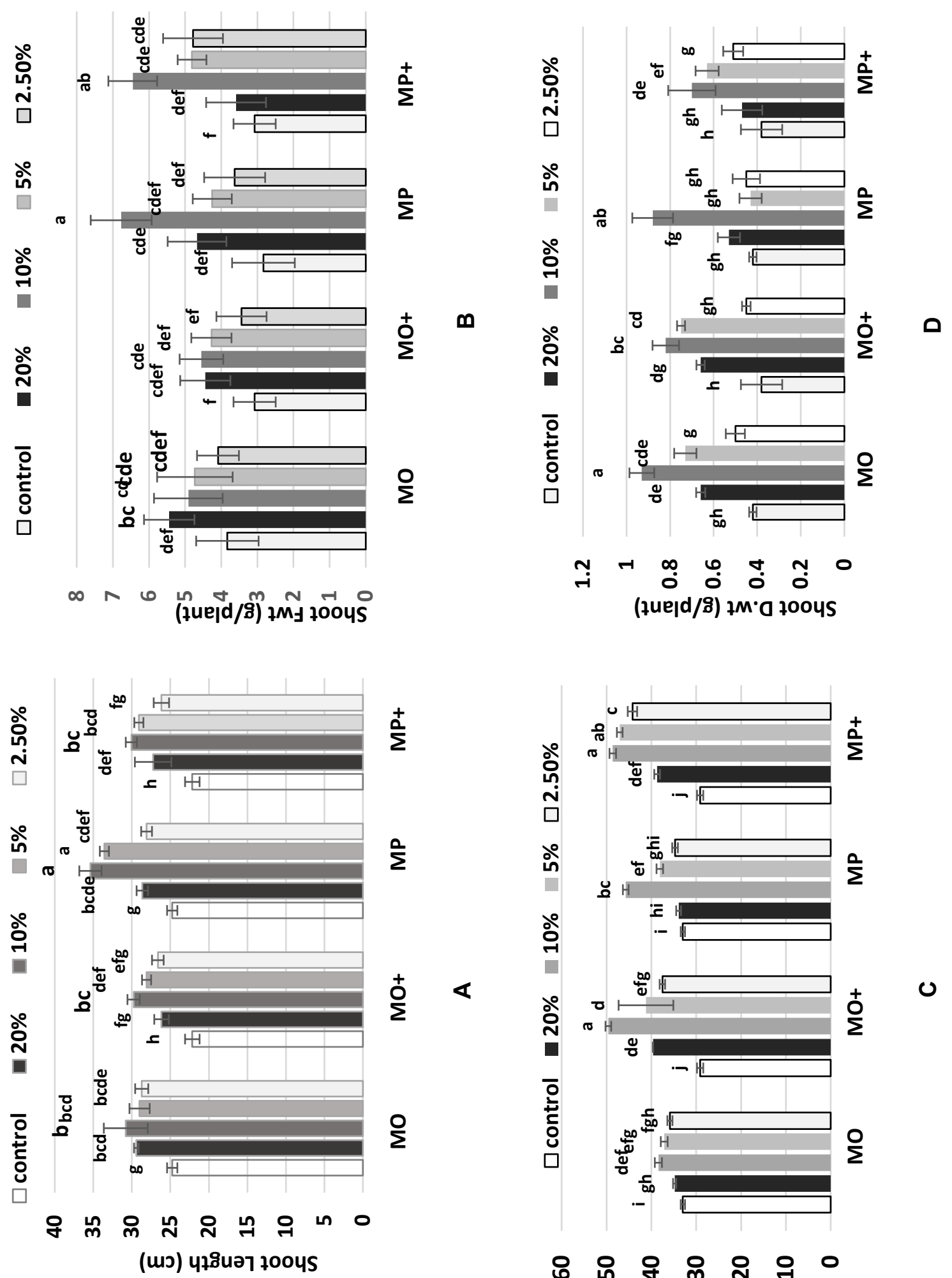

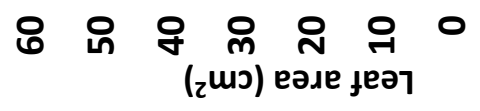




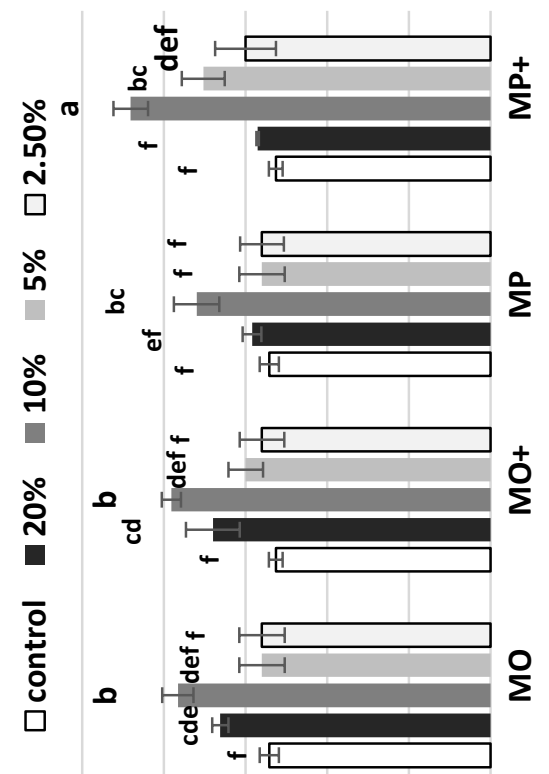

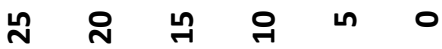
(யว) บ78ิน⿰丬 700y

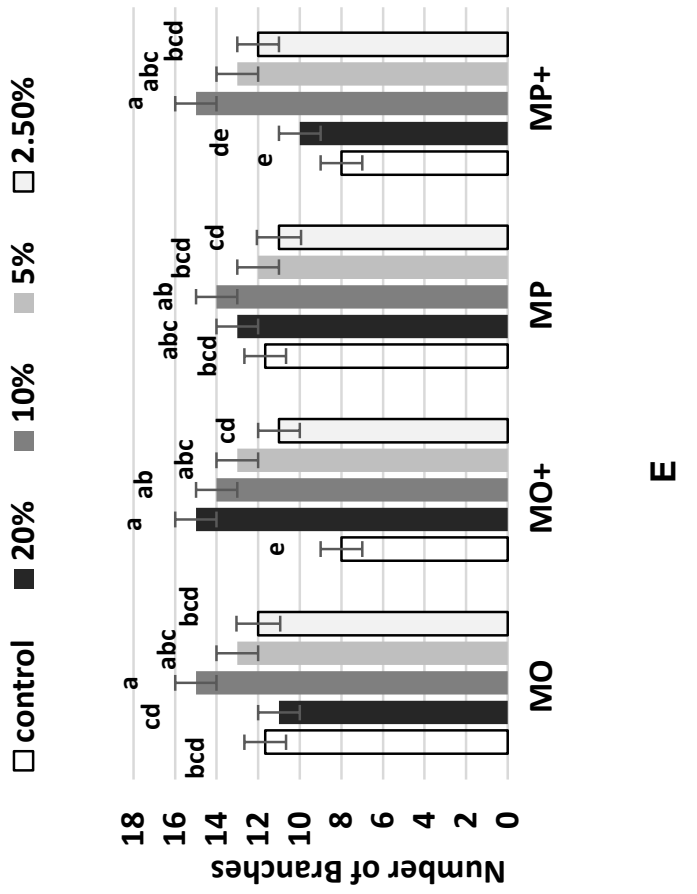

ᄂ

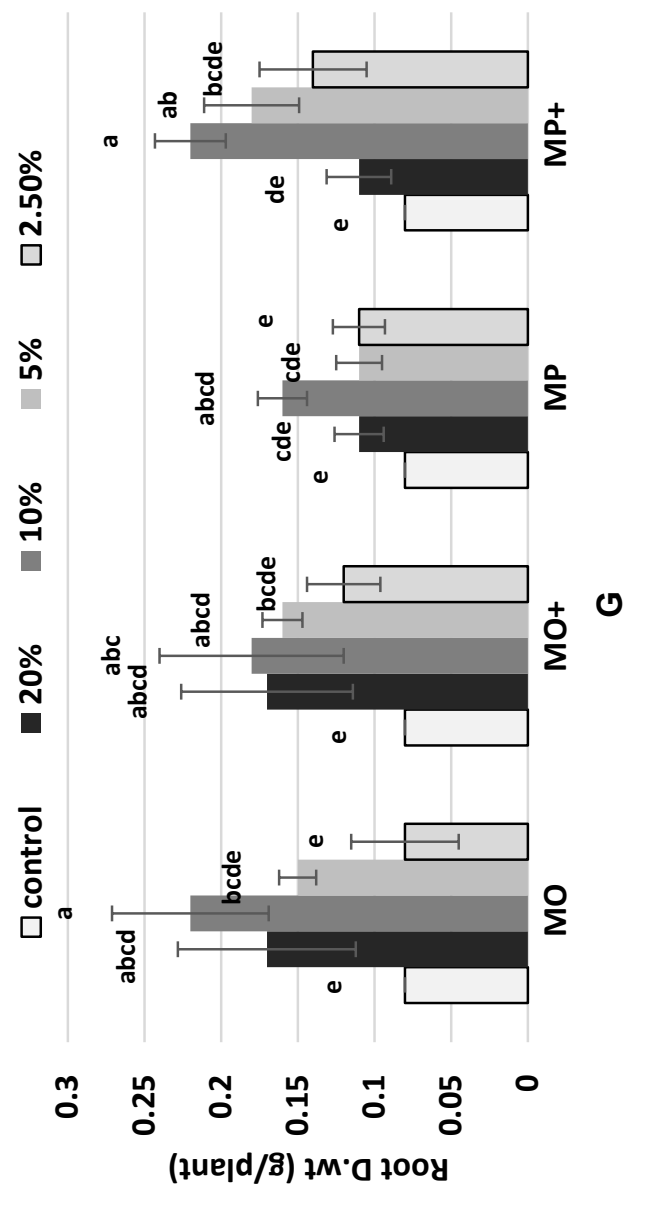


Salt- free experiment

Irrigating salt-free experiments using Moringa leaf extracts resulted in $33 \%$ and $46 \%$ increase of shoot length, $25 \%$ and $134 \%$ increase in shoot fresh weight, $18 \%$ and $40 \%$ enlargement of leaf area, with MO and MP treatments, respectively (Fig. 1 A-C). Furthermore, the increase of shoot dry weight exceeded $131 \%$ and $119 \%$, number of branches increased by $25 \%$ and $16.6 \%$, root length by $28 \%$ and $21 \%$, and root dry weight increased by $193 \%$ and $100 \%$ upon using MO and MP extracts for irrigation, respectively (Fig. $1 \mathrm{D}-\mathrm{G}$ ).

Interaction of Moringa extracts and salinity on the metabolic activity of sweet basil

The anthocyanin pigment content has increased in six weeks-old basil due to $10 \% \mathrm{MO}$ and MP applications in salt experiments by $30 \%$ and $13.5 \%$, respectively (Fig. 2 A). Alternatively, proline in basil leaf has decreased significantly by $57 \%$ and $60 \%$ with MO and MP, respectively (Fig. 2 B). Total carbohydrates increased by $80 \%$ and 14\% (Fig. 2 C) and malondialdehyde (MDA) was reduced in basil leaf by $18.6 \%$ and $66 \%$ (Fig. 2 D) when MO and MP were applied, respectively. The activities of antioxidant enzymes increased due to salinity stress and diminished with treatments of MO and MP leaf extracts. For example, superoxide dismutase (SOD) in basil leaf reduced by $26 \%$ with MO and by $48 \%$ with MP treatment (Fig. 3 A). The catalase (CAT) enzyme activity had also been reduced with the treatments by $37 \%$ in basil leaf (Fig. 3 B). Ascorbic acid oxidase (ASO) activity was reduced significantly upon Moringa treatments by $61 \%$ with MO and up to $56 \%$ with MP extract (Fig. $3 \mathrm{C}$ ). The peroxidase (POX), ascorbic peroxidase (APX) and polyphenol oxidase (PPO) in basil leaf have decreased with non-significant change between both Moringa species. Thereby, the average reduction values were $34 \%$ for peroxidase, $31 \%$ of ascorbic peroxidase and $36 \%$ for polyphenol oxidase (Fig. 3 D-F).

\section{Discussion}

Several reasons were responsible for the variations of plant growth and metabolic activity under salt stress such as the primary inhibitory effect of water and essential ions uptake (Marschner, 2012). The impairment of photosynthesis, the decrease of metabolic enzymes besides alterations of carbohydrates metabolism and hormonal homeostasis (Gao et al., 1998; Chartzoulakis et al., 2002; Munns, 2002 and Tabatabaei, 2006). Salinity primary effect in generating species of reactive oxygen like singlet oxygen and hydrogen peroxide and induced malondialdehyde was reported (Wildt et al., 1997). In agreement with previous findings, our data confirmed the elevation of both proline and the activity of multiple antioxidant enzymes such as: Superoxide dismutase (SOD), catalase (CAT), ascorbic acid oxides (ASO), peroxidase (POX), ascorbate peroxidase (APX) and polyphenol oxidase under salinity stress (Ben-Taarit et al., 2009; Rady et al., 2013; Yasmeen et al., 2013 and Howlader, 2014). Due to salinity, symptoms of ionic toxicity have frequently appeared in forms of malfunction of water relations (Hussein et al., 2012) and in the decreased chlorophyll content due to destruction of pigment-protein complex which subsequently led to a reduction of dry matter (Santos, 2004 and Ashraf \& Harris, 2013). Furthermore, salinity effect in reducing the growth rates of leaf and root, leaf area and lateral branches (Läuchli \& Grattan, 2007) could be ascribed to the known salinity effect regarding the inhibition of cell division and cell enlargement in the growing point (Kulshrestha et al., 2013).

Generally, Moringa crude aqueous extract encloses mixture of various categories of active compounds that possess biostimulanting properties such as, carbohydrates, nitrogenous compounds, hormones and polyphenols (Talreja, 2011; Ahmed et al., 2016 and Said Al-Ahl et al., 2017). The role of MP as biostimulant was particularly important for its known richness in both ascorbic acids and reduced glutathione (Luqman et al., 2012). Every category is imposing its physiological impact either separately or simultaneously during alleviation of salinity symptoms in sweet basil. For example, the minerals effect in targeting $\mathrm{pH}$ regulation, homeostasis, osmosis, enzymes and signalingwas studied (Pilon-Smits et al., 2009). In a previous study, external application of calcium had ameliorated chlorophyll loss in plants (Yasmeen et al., 2013). Apart from the literature which reported that calcium content in MO was four times as much as in milk (Foidle et al., 2001), our data showed that both Moringa species were calcium-rich, and that MP enclosed higher amounts of calcium compared to MO (Asghari et al., 2015). The biochemical content of MP also revealed potassium richness (Asghari et al., 2015). Potassium is the element known to alleviate salinity in stressed plants through balancing $\mathrm{Na}^{+}$: 
$\mathrm{K}^{+}$ratio and via ameliorating stomatal conductance and turgor maintenance (Mengel \& Kirkby, 2001). Compared to $\mathrm{MO}$, iron was almost two folds higher in MP extract. Iron is crucial, possessing biological effect on plants, particularly during photosynthesis and DNA synthesis. Furthermore, iron is involved with chlorophyll synthesis and participates in chloroplast maintained structure and function. It is also the prosthetic groups of many antioxidant enzymes like the catalase, peroxidase, cytochromes and cytochrome oxidases and links with the last step of respiration (Rout \& Sahoo, 2015).

As previously reported, the effect of Moringa leaf extract was concentration-dependent, and that the diluted extracts could be promotive, whereas the concentrated ones might be suppressive, likely due to the hormonal mode of action (Khan et al., 2009). Current data showed that $10 \%$ Moringa leaf extract was the dose seemed appropriate offering the best effect among all. Thus, we initially used $10 \%$ as a key concentration that confers the highest level of recovery. Moreover, we also confirmed that the variance in the biochemical composition of Moringa species had imposed varied tolerance strategies in sweet basil plant. For example, MP richness in hormones had supported length of shoot and root and improved shoot fresh weight compared to MO. Alternatively, the soluble sugars, nitrogenous compounds, amino nitrogen and total phenols of MO leaf extract have improved growth and slightly had affected shoot fresh weigh, root length, number of branches and root dry weight.

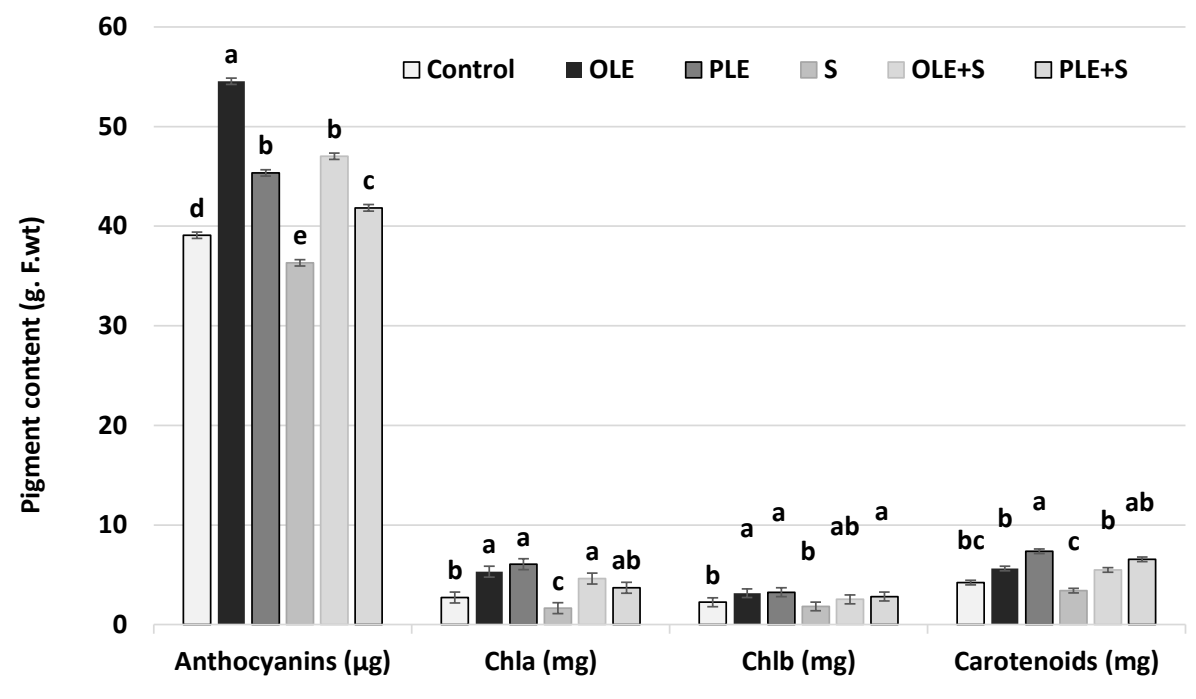

A

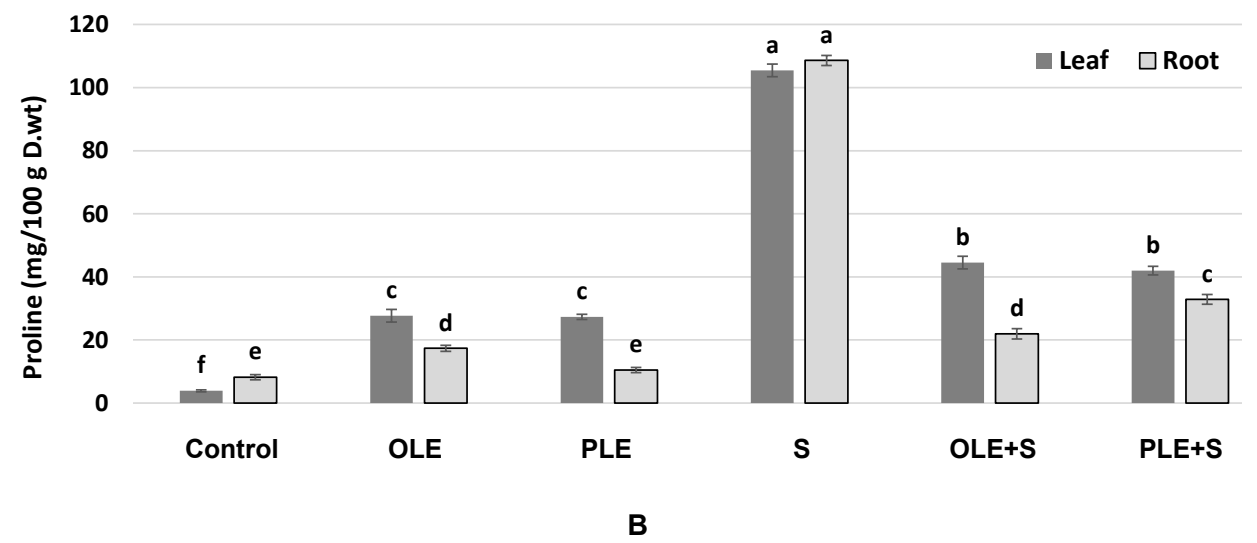


25
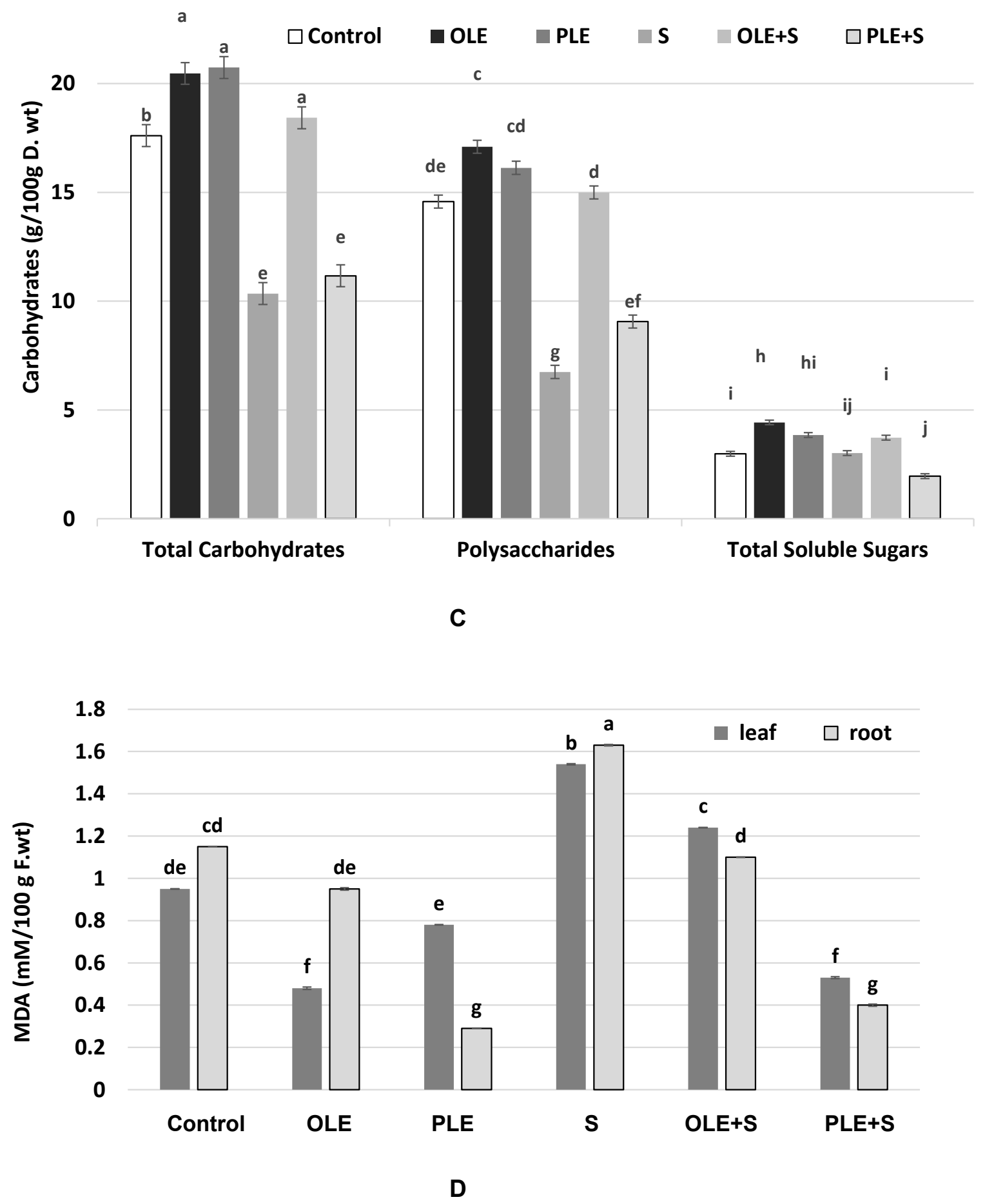

Fig. 2. Effect of leaf extracts concentration (10\%) from Moringa oleifera (OLE) and Moringa peregrena (PLE) on the biochemical activities of sweet basil plant during exposure to $100 \mathrm{mM} \mathrm{NaCl}(\mathrm{S})$. Pigment, A; proline, B; carbohydrates, $C$ and malonyldialdehyde (MDA, D). Combined salt to M. oleifera extracts in basil experiment; OLE+S. Salt combined to M. peregrena extract; PLE+S. 


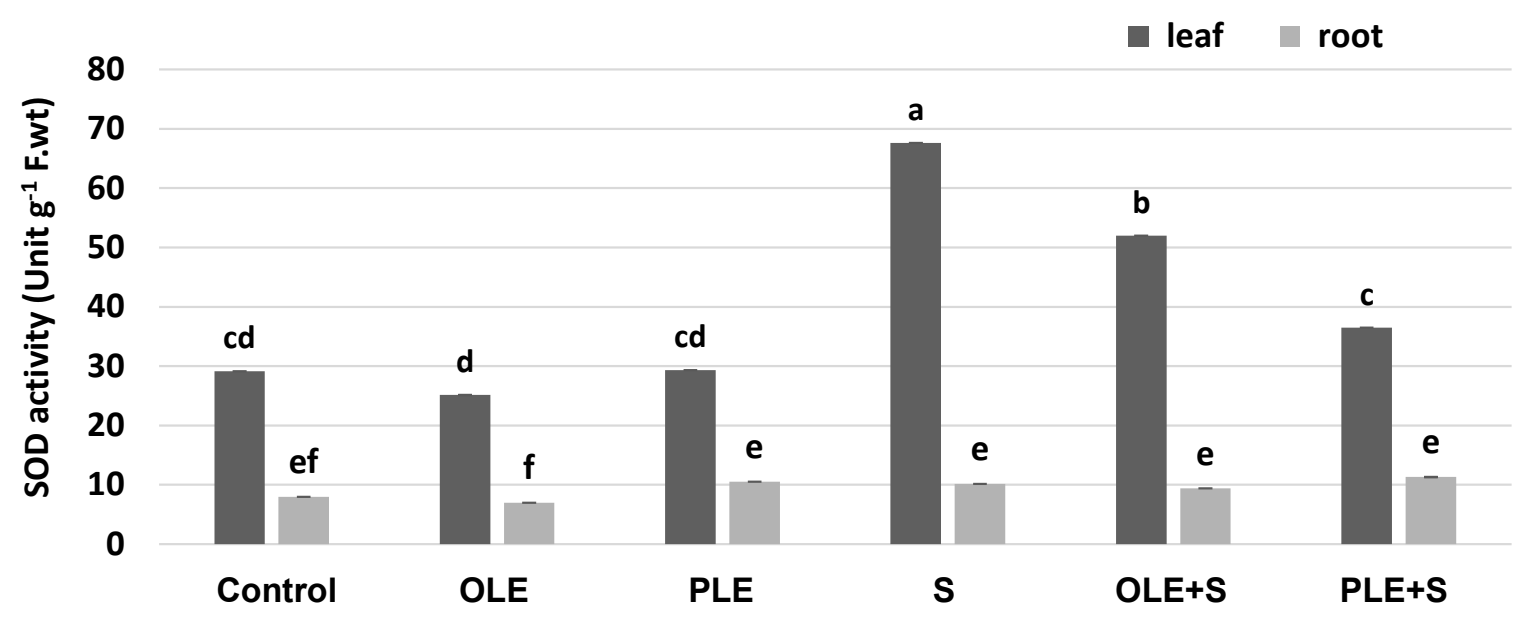

A


Egypt. J. Bot. 59, No.2 (2019) 

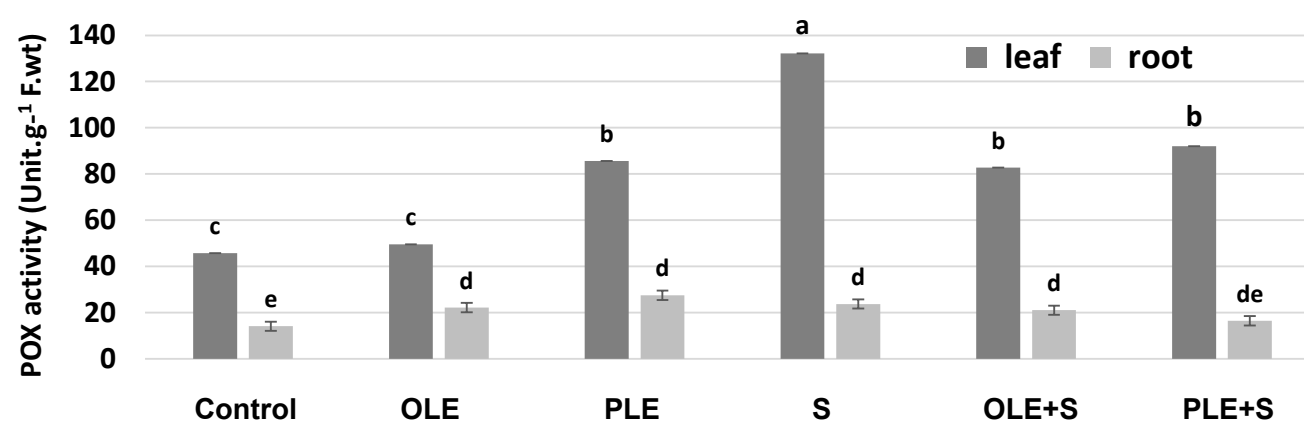

D
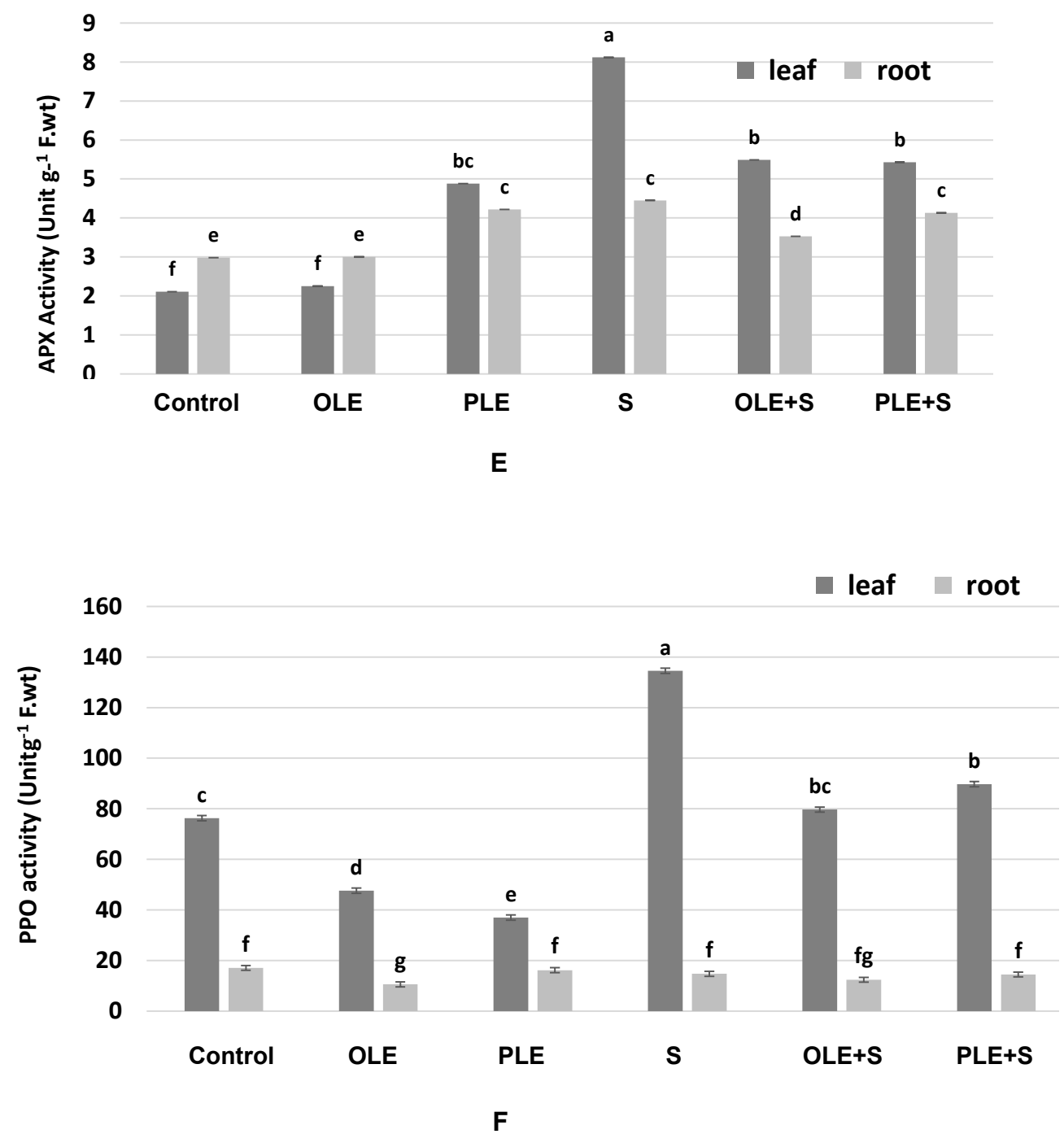

Fig. 3. Antioxidant enzymes activity of sweet basil leaf and root. Grown basil under the effect of $100 \mathrm{mM} \mathrm{NaCl}$ alone; S. Salt-free basil treated with $10 \%$ leaf extracts from Moringa oleifera (OLE) or Moringa peregrena (PLE). The combined effects of $100 \mathrm{mM} \mathrm{NaCl}$ and $10 \%$ Moringa oleifera extract on basil; OLE $+\mathrm{S}$ and of $100 \mathrm{mM} \mathrm{NaCl}$ and $10 \%$ Moringa peregrena extract; PLE $+\mathrm{S}$. Superoxide dismutase, A; catalase, B; ascorbic acid oxides, $C$; peroxidase, $D$; ascorbate peroxidase, $E$ and polyphenol oxidase, $F$. 
Some phenolic compounds of MO were absent in MP. Yet, no published data on the role of MO phenols as biostimulants were found. Apparently, basil had utilized MO overall metabolic constituents to enhance and maintain tolerance during salinity stress via raising the antioxidant enzymes activity. On the other hand, the MP defense strategy was dependent on using salicylic acid, the kind of phenols that frequently reported as crucial regulators of physiological processes the tolerance inducer of abiotic stress in many plants (Kaya et al., 2009 and Hayat et al., 2010). In addition, MP encloses hormones, elements and reduced glutathione found important for both induction and activation of cellular hydrogen peroxide antioxidant enzymes in basil like CAT and POX, the participating enzymes with metabolic processes such as, photorespiration, polymerization of phenols to lignin and in the glycolytic pathway (Romheld et al., 1984 and Abogadalla, 2010). Ascorbic acid and glutathione, the potent antioxidants of low molecular weight had relatively accumulated in substantial amounts in MP compared to MO (Blokhina et al., 2003). Ascorbic acid, on one hand, is the small metabolite that participates in the cellular detoxification of hydrogen peroxide (Noctor \& Foyer, 1998) and in cell division of plant (Smirnoff, 2011). It further assists membrane protection via tocopherol regeneration (Thomas et al., 1992). In a previous report, the mitigation effect of ascorbic acid exceeded that of glutathione in olive plants subjected to salinity using $100 \mathrm{mM} \mathrm{NaCl}$ (Aliniaeifard et al., 2016). Herein, ascorbic acids-rich plants like MP activate ascorbic acid oxidation (ASO) enzyme in basil. ASO is the interfering enzyme with ascorbic acids oxidation and metabolism. Moreover, the reduced glutathione had reacted during stress as non-enzymatic scavenger of hydrogen peroxide, superoxide and singlet oxygen (Larson, 1988). Furthermore, the consequent effect of increased activity of reduced glutathione on stimulating cotton plants tolerance to salt stress was also discovered (Melonia et al., 2003).

In this study, it is proposed the presence of an inversely relationship between the declined MDA level and the increased antioxidant enzymes scavenging capacity in basil with MP treatment. It can be suggested that the biochemical compounds like the reduced glutathione, ascorbic acids, hormones and minerals were actively higher regarding their efficacy as biostimulants as compared to the total phenolic content present in MO. However, each Moringa species had separately played the same essential role in enhancing the overall antioxidant enzymes pool and hence, basil tolerance. The abundance of MP ascorbic acids and reduced glutathione must had replenished the degraded ascorbic acid and glutathione in basil due to salinity as recorded (Valderrama et al., 2006).

\section{Conclusion}

The current study indicated that salinity in basil was the detriment that could be healthily encountered using environmental risk-free methods such as leaf extracts from MO and MP as biostimulants. Tolerance in basil was a compatible associated strategy with the biochemical profile in Moringa species. For future investigations, we presume that a full recovery from salt stress would be likely obtained in basil under the effect of mutual or simultaneous irrigation using low doses of Moringa leaf extracts.

Acknowledgements: The authors thank Ain Shams University for facilities.

\section{References}

Abd El-Wahab, R.H., Zaghloul, M.S. and Moustafa, A.A. (2004) Conservation of medicinal plants in St. Catherine Ptotectorate, South Sinai. I. Evaluation of ecological status and human impact. Proceedings of First International of Conference on Strategy of Egyptian Herbaria. (Giza, Egypt), pp. 231-251.

Abdel Latef, A.A. (2010) Changes of antioxidative enzymes in salinity tolerance among different wheat cultivars. Cereal Research Communications, 38, 4355.

Abogadallah, G.M. (2010) Antioxidative defense under salt stress. Plant Signaling \& Behavior, 5, 369-374.

Aliniaeifard, S., Hajilou, J., Tabatabaei, S.J. and SifiKalhor, M. (2016) Effects of ascorbic acid and reduced glutathione on the alleviation of salinity stress in olive plants. International Journal of Fruit Science, 16, 395-409.

Ahmed, K.S., Banik, R., Hossain, M.H. and Ismet Ara Jahan, I.A. (2016) Vitamin C (L-ascorbic acid) content in different parts of Moringa oleifera grown in Bangladesh. American Chemical Science Journal, 11, 1-6.

Alkahtani, H.A. and Abou- Arab, A.A.

(1993) 
Comparison of physical, chemical and functional properties of Moringa peregrena (Al-Yassar or AlBan) and soybean proteins. Cereal Chemistry, 70, 619-626.

Alscher, R.G., Erturk, N. and Heath, L.S. (2002) Role of superoxide dismutases (SODs) in controlling oxidative stress in plants. J. Exp. Bot. 53, 1331-1341.

Asghari, G., Palizban, A. and Bakhshaei, B. (2015) Quantitative analysis of the nutritional components in leaves and seeds of the Persian Moringa peregrina (Forssk.) Fiori. Pharmacognosy Research, 7, 242248.

Ashraf, M. and Harris, P.J.C. (2004). Potential biochemical indicators of salinity tolerance in plants. Scientia Horticulturae Amesterdam, 166, 3-6.

Ashraf, M. and Harris, P.J.C. (2013) Photosynthesis under stressful environments: An overview. Photosynthetica, 5, 63-190.

Aydemir, T. and Erez, Z. (2010) Physiological and biochemical response to $\mathrm{NaCl}$ stress in Lens culinaris. C.B.U. Journal of Science, 62, 89-104.

Basra, S.M.A., Zahar, M., Rehman, H., Yasmin, A. and Munir, H. (2009). Evaluating the response of sorghum and Moringa leaf aqueous extracts on seedling growth in hybrid maize. In: Proceedings of the international conference on sustainable food grain production: Challenges and Opportunities, University of Agriculture, Faisalabad, Pakistan, p 22 .

Battacharyya, D., Babgohari, M.Z., Rathor, P. and Prithiviraj, B. (2015) Seaweed extracts as biostimulants in horticulture. Scientia HorticulturaeAmesterdam, 196, 39-48.

Bates LS, Waldren RP, Tear ID (1973). Rapid determination of free proline for water-stress studies. PlantandSoil. 39: 205-207.

Becker, B. (2013) Snowball earth and the split of Streptophyta and Chlorophyta. Trends in Plant Science, 18, 180-183.

Ben-Taarit, M.K., Msaada, K., Hosni, K.M., Hammami, M., Kchouk, E. and Marzouk, B. (2009) Plant growth, essential oil yield and composition of saga (Salvia officinalis L.) fruits cultivated under salt stress conditions. Industrial Crops and Products, 30,
333-337.

Blokhina, O., Virolainen, E. and Fagerstedt, K.V. (2003) Antioxidants, oxidative damage and oxygen deprivation stress: A review. Annals of Botany (Lond), 91, 179-194.

Chartzoulakis, K.M., Loupassaki, M., Bertaki, I. and Androulakis, I. (2002) Effects of $\mathrm{NaCl}$ salinity on growth, ion content and $\mathrm{CO}_{2}$ assimilation rate of six olive cultivars. Scientia Horticulturae-Amesterdam, 96, 235-247.

Colla, G. and Rouphael, Y. (2015) Biostimulants in horticulture. Scientia Horticulturae-Amesterdam, 196, 1-2.

Colla, G., Nardi, S., Cardarelli, M., Ertani, A., Lucini, L., Canaguier, R. and Rouphael, Y. (2015) Protein hydrolysates as biostimulants in horticulture. Scientia Horticulturae-Amesterdam, 1196, 28-38.

Craigie, J.S. (2011) Seaweed extract stimuli in plant science and agriculture. Journal of Applied Phycology, 23, 371393.

Diallins, G., Pateraki, I., Sanmartin, M., Scossa, A., Stillianou, E., Panopoulos, N.J. and Kanellis, A.K. (1997) Melon ascorbate oxidase: Cloning of a multigene family, induction during fruit development and repression by wounding. Plant Molecular Biology, 34, 759-770.

Du Jardin, P. (2015) Plant biostimulants: Definition, concept, main categories and regulation. Scientia Horticulturae-Amesterdam, 196, 3-14.

Fiazi, B.S., Siddiqui, R., Saleem, S., Siddiqui, S., Aftab, K. and Gilani, A.H. (1995) Fully accelerated carbamates and hypotensive thiocarbamate glycosides from Moringa oleifera. Phytochemistry, 38, 957-963.

Foidle, G., Makkar, H.P.S. and Becker, K. (2001) The potential of Moringa oleifera for agricultural and industrial uses. In: "The Miracle Tree: The Multipurpose Attributes of Moringa", Fugile, L. (Ed.), pp. 45-76. CTA. Publications Wageningen. The Netherlands.

Gao, Z., Sagi, M. and Lips, S. (1998) Carbohydrate metabolism in leaves and assimilate partitioning in fruits of tomato (Lycopersicon esculentum L.) as affected by salinity. Plant Science, 135, 149-159. 
Hayat, Q., Hayat, S., Irfan, M. and Ahmad, A. (2010) Effect of exogenous salicylic acid under changing environment: A review. Environmental and Experimental Botany, 68, 14-25.

Heath, R.L. and Packer, L. (1968) Photoperoxidation in isolated chloroplasts. I. Kinetics and stoichiometry of fatty acid peroxidation. Archives of Biochemistry and Biophysics, 125, 189-198.

Howlader, S.M. (2014) A novel Moringa oleifera can leaf extract mitigate the stress effect of salinity and cadmium in bean (Phaseolus vulgaris) plants. Ecotoxicology and Environmental Safety, 100, 6975.

Hussain, M.M., El-Faham, S.Y. and Alva, A.K. (2012) Pepper plants growth, yield, photosynthetic pigments and total phenols as affected by foliar application of potassium under different salinity irrigation water.Agricultural Science, 3, 241-248.

Kar, M. and Mishra, D. (1976) Catalse, peroxidae, and polyphenol oxidase activities during rice leaf senescence. Plant Physiology, 57, 315-319.

Kardpol, R.P. and Rao, N.A. (1985) Alterations in the biosynthesis of proteins and nucleic acids in linger millet (Eleucine carocana) seedlings during water stress and effect of proline on protein biosynthesis. Plant Science, 40, 3-79.

Kaya, C., Tuna, A. and Yokaş, I. (2009) "Salinity and Water Stress", pp. 45-50. Springer, Netherlands.

Khan, W., Rayirath, U.P., Subramanian, S., Jithesh, M.N., Rayorath, P., Hodges, D.M., Critcheley, A.T., Craigie, J.S., Norrie, J. and Prithiviraj, B. (2009) Seaweed extracts as biostimulants of plant growth and development. Journal of Plant Growth Regulation, 28, 386-399.

Koricheva, J., Roy, S., Vranjic, J.A., Haukioja, E., Hughes, P.R. and Hanninen, O. (1997) Antioxidant response to simulated acid rain and heavy metal deposition in birch seedlings. Environmental Pollution, 95, 249-258.

Kulshrestha, V., Singh, B., Meena, S.K. and Dixit, S. (2013) Seed germination studies on Vicia faba L. under salt stress. Indian Research Journal of Gene Biotechnology, 5, 178-185.
Larson, R.A. (1988) The antioxidants of higher plants. Phytochemistry, 27, 969-978.

Läuchli, A. and Grattan, S.R. (2007) Plant growth and development under salinity stress. In: "Advances in Molecular Breeding Toward Salinity and Drought Tolerance". M.A. Jenks, P.A. Hasegawa and S. M Jain (Eds.), pp.1-31. Springer-Verlag.

Luqman, S., Srivastava, S., Kumar, R., Maurya, A.K. and Chanda, D. (2012) Experimental assessment of Moringa oleifera leaf and fruit for its antistress, antioxidant, and scavenging potential using in vitro and in vivo assays. Evidence-based Complementary and Alternative Medicine, 51, 9084.

Mahmood, K.T., Mugal, T. and Haq, I.U. (2010) Moringa oleifera: A natural gift-a review. Journal of Pharmaceutical Sciences and Research, 2, 775781.

Marklund, S. and Marklund, G. (1974) Involvement of the superoxide anion radical in the autoxidation of pyrogallol and a convenient assyay for superoxide dismutase. European Journal of Biochemistry, 47, 469-474.

Marschner, P. (2012) "Marschner's Mineral Nutrition of Higher Plants". $3^{\text {rd }}$ ed. Academic Press, London, UK.

Makri, O. and Kintzios, S. (2007) Ocimun sp. (basil): Botany, cultivation, pharmaceutical properties and biotechnology. Journal of Herbs, Spices \& Medicinal Plants, 13, 123-150.

Melonia, A.D., Olivaa, M.A., Martineza, C.A. and Cambraiab, J. (2003) Photosynthesis and activity of superoxide dismutase, peroxidase and glutathione reductase in cotton under salt stress. Experimental and Environmental Botany, 49, 69-76.

Meneghel, A.P., Gonclaves, J.R., Rubio, F., Draguniski, D.C., Lindino, C.A. and Strey, L. (2013)Biosorption of cadmium from water using Moringa (Moringa oleifera Lam) seeds. Water Air and Soil Pollution, 224, 1383-395.

Mengel, K. and Kirkby, E.A. (2001) "Principles of Plant Nutrition". $5^{\text {th }}$ ed., Kluwer Academic Publishers, Dordrecht.

Metzner, H., Raum, H. and Senger, H. (1965) Unterschungen Zur Synchno-nisier-Barkeit inze- 
Iner Pigmenmangel-Mutanten-von. Chlorella. Planta, 65, 186.

Munns, R. (2002) Comparative physiology of salt and water stress. Plant Cell and Environment, 25, 239250 .

Munns, R. and Tester, M. (2008) Mechanisms of salinity tolerance. Annual Review of Plant Physiology, 59, 651-681.

Mukheriee, S.P. and Choudhuri, M.A. (1983) Implication of water stress-induced changes in the level of endogenous ascorbic acid and hydrogen peroxide in Vigna seedling. Physiologiae Plantarum, 58, 166170.

Noctor, G. and Foyer, C.H. (1998) Ascorbate and glutathione: Keeping active oxygen under control. Annual Review of Plant Biology, 49, 249-279.

Olson, M. (2002) Combining data of DNA sequences and morphology for a phylogeny of Moringaceae (Brassicales). American Society of Plant Taxonomists. Systematic Botany, 27, 55-73.

Pilon-Smits, E.A.H., Quinn, C.F., Tapken, W., Malagoli, M. and Schiavon, M. (2009) Physiological functions of beneficial elements. Current Opinion in Plant Biology, 12, 267-274.

Price, M.L. (2000) The Moringa tree. Echo Technical Note. Published-1985

Rady, M.M. (2011) Effect of 24-epibrassiolide on growth, yield, antioxidant system and cadmium content of bean (Phaseolus vulgaris L.) plants under salinity and cadmium stress. Scientia HorticulturaeAmesterdam, 129, 232-237.

Rady, M.M., Bhavya, V.C. and Howladar, S.M. (2013) Common bean (Phaseolus vulgaris) seedlings overcome $\mathrm{NaCl}$ stress as a result of presoaking in Moringa oleifera leaf extract. Scientia HorticulturaeAmesterdam, 162, 63-70.

Romheld, V., Muller, C. and Marschner, H. (1984) Localization and capacity of proton pumps in roots of intact sunflower plants. Plant Physiology, 76, 603606.

Rout, G.R. and Sahoo, S. (2015) Role of iron in plant growth and metabolism. Reviews in Agricultural Science, 3, 1-24.
Saeidnejad, A.H., Pasandi-Pour, A., Pakgohar, N. and Farahbakhsh, H. (2013) Effects of exogenous nitric oxide on germination and physiological properties of basil under salinity stress. Journal of Medicinal Plants and Byproducts, 1, 103-113.

Said Al-Ahl, H., Hikal, W. and Mahmoud, A.A. (2017) Biological activity of Moringa peregrina: A review 1. A brief history and uses of Moringa peregrine. American Journal of Food Science and Health, 3, 83-87.

Sajjadi, S.E. (2006) Analysis of the essential oils of two cultivated basil (Ocimum basilicum L.) from Iran. DARU Journal of Pharmaceutical Sciences, 14, 128-130.

Santos, C.V. (2004). Regulation of chlorophyll biosynthesis and degradation by salt stress in sunflower leaves. Scientia HorticulturaeAmesterdam, 103, 93-99.

Saqib, Z.A., Akhtar, J., Ul-Haq, M.A. and Ahmed, I. (2012) Salt induced changes in leaf phenology of wheat plants are regulated by accumulation and distribution pattern of $\mathrm{Na}^{+}$ion. Pakistan Journal of Agricultural Sciences, 49, 141-148.

Sharma, N., Gupta, N.K., Gupta, S. and Hasegawa, H. (2005) Effect of $\mathrm{NaCl}$ salinity on photosynthesis rate, transpiration rate, and oxidative stress tolerance on contrasting wheat genotype. Photosynthetica, 43, 609-613.

Sheng, M., Tang, M., Chan, H., Yang, B., Zhang, F. and Huang, Y. (2008) Influence of arbuscular mycorrhizae on photosynthesis and water status of maize plants under salt stress. Mycorrhiza, 18, 287 296.

Siddhuraju, P. and Becker, K. (2003) Antioxidant properties of various solvent extracts of total phenolic constituents from three different agroclimatic origins of drumstick tree (Moringa oleifera L.) leaves. Journal of Agricultural and Food Chemistry, 51, 2144-2155.

Silva, C., Martinez, V. and Carajal, M. (2008) Osmotic versus toxic effects of $\mathrm{NaCl}$ on pepper plants. Biologia Plantarum, 52, 72-79.

Simon, J.E., Quinn, J. and Murray, R.G. (1990) Basil: A source of essential oils. In: "Advances in New Crops", Janick, J., Simon, J.E. (Eds.), pp. 484-489. 
Timber Press, Portland, OR.

Smirnoff, N. (2011) Vitamin C: The metabolism and functions of ascorbic acid in plants. Advances in Botanical Research, 59, 107-177.

Tabatabaei, S. (2006) Effects of salinity and $\mathrm{N}$ on the growth, photosynthesis and $\mathrm{N}$ status of olive (Olea europaea L.) trees. Scientia Horticulturae, 108, 432-438.

Talreja, T. (2011) Biochemical estimation of three primary metabolites from medicinally important plant Moinga oleifera. International Journal of Pharmaceutical Sciences Review and Research, 7, 196-188.

Thomas, C.E., McLean, L.R., Parker, R.A. and Ohlweiler, D.F. (1992) Ascorbate and phenolic antioxidant interactions in prevention of liposomal oxidation. Lipids, 27, 543-550.

Valderrama, R., Corpas, F.J., Carreras, A., GomezRodriguez, M.V., Chaki, M., Pedrajas, J.R., Fernandez-Ocana, A., Del Rio, L. and Barroso, J.B. (2006) The dehydrogenase-mediated recycling of $\mathrm{NADPH}$ is a key antioxidant system against saltinduced oxidative stress in olive plants. Plant Cell and Environment, 29, 1449-1459.

Vranova, V., Rejsek, K., Skene, K.R. and Formanek, P. (2011) Non-protein amino acids; plant, soil and ecosystem interactions. Plant and Soil, 342, 31-48.

Wada, M., Kishikawa, N., Kuroda, N. and Nakashima, K. (2008) Evaluation method for antioxidative activity of health food. In: "Food Chemistry Research Developments", Papadopoulos, K. N. (Ed.), pp. 199-221. Nova Science Publishers, New York.

Whistler, R.L., Wolform, M.L., Bemiller, J.N. and Shafizadeh, F. (1962) Anthrone coluorimetric method. In: "Methods in Carbohydrate Chemistry", Acadimic Press, New York, London. Vol.1, 384p.

Wildt, J., Kley, D., Rockel, A. and Segschneider, H.J. (1997) Emission of NO from higher plant species. Journal of Geophysical Research-Atmospheres, 102, 5919-5927.

Yasmeen, A., Basraa, S.M., Farooq, M., Rehman, H., Hussein, N. and Athar, H.R. (2013) Exogenous application of moringa leaf extract modulates the antioxidant enzyme system to improve wheat performance under saline conditions. Plant Growth Regulation, 69, 225-233.

Zhu, J.K. (2001) Plant salt tolerance. Trends in Plant Science, 6, 66-71.

(Received 30/10/2018; accepted 10/1 /2019)

\section{استخدام مستخلصات أوراق نبات المورينجا كمفزات بيولوجية لتدعيم صفة مقاومة الأجهاد الملحي في نبات الريحان \\ رئيفة أحمد حسنين، أمل فضل عبد القادر، هبه محمد فرماوي

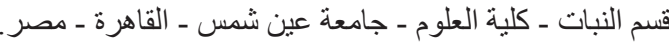

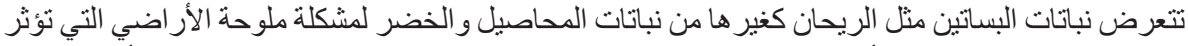

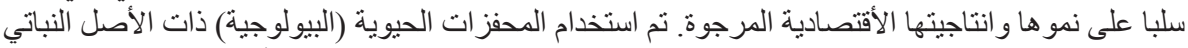

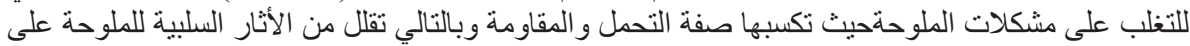

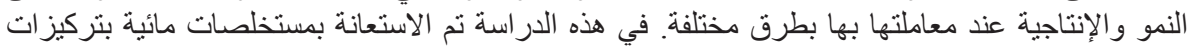

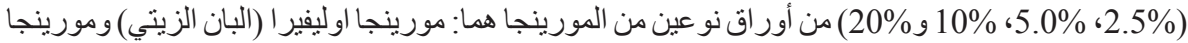



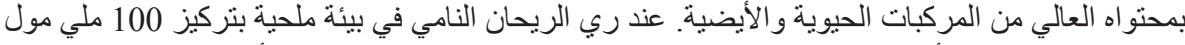

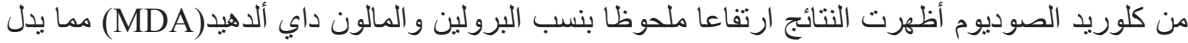

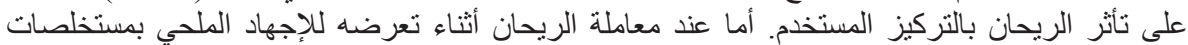

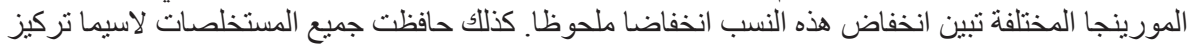

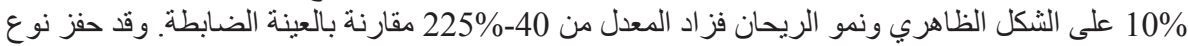



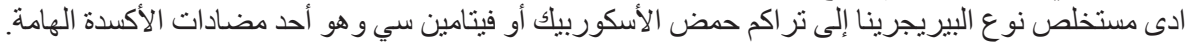

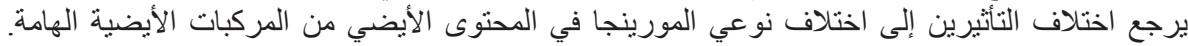


وتوصي الدر اسة باستخدام النو عين معا بالتبادل لمزيد من المقاومة ولن لإنتاجية أفضل. 